\title{
PEMBELAJARAN FISIKA DENGAN MODEL SIKLUS BELAJAR 5-E (ENGAGE, EXPLORE, EXPLAIN, ELABORATE, EVALUATE) SEBAGAI UPAYA MENINGKATKAN KECAKAPAN HIDUP SISWA
}

\author{
Hikmawati \\ Program Studi Pendidikan Fisika \\ Universitas Mataram \\ Mataram, Indonesia \\ Email : hikmawati.fisika@yahoo.com
}

\begin{abstract}
Life skills of students and teachers in the Province of West Nusa Tenggara, especially the island of Lombok is still low. Development of life skills is not optimal attention of government and education observers. Life Skills is a skill that must have to dare to face the problems of life and everyday life with a reasonable without feeling depressed, then proactively and creatively search for and find a solution so as to cope. Life skills can be developed through classroom learning, including learning physics. Physics should be viewed as a process and at the same time so that the product in physics learning two things must be taken into consideration in choosing a model of learning that the learning process can be both effective and efficient. Application of the learning cycle model of 5-E (Engage, Explore, Explain, Elaborate, Evaluate) may be an alternative for teachers to achieve the expected learning goals. This model can facilitate active learning in exploratory activities through interaction with the teacher, as well as with other students. Thus, the application of the learning cycle model of 5-E in learning physics is expected to increase students' life skills.
\end{abstract}

Keywords : learning physics, learning cycle, life skills

\section{PENDAHULUAN}

Tingkat kecakapan hidup siswa maupun guru di Pulau Lombok masih tergolong rendah. Menurut [1], pengembangan kecakapan hidup, salah satunya adalah keterampilan berpikir tingkat tinggi, masih belum mendapat perhatian yang optimal dari pemerintah maupun pemerhati pendidikan. Hasil penelitian [2] menemukan data bahwa tingkat kemelekan sains (science literacy) guru SLTP di Propinsi NTB berada pada skor rata-rata sebesar $46 \%$ sedangkan tingkat kemelekan inkuiri (inquiry literacy) berada pada skor rata-rata sebesar 56\%. Data hubungan antara pengalaman mengajar dan skor kemelekan sains dapat dilihat pada Tabel 1 berikut ini.

Tabel 1. Tingkat Kemelekan Sains

\begin{tabular}{|c|c|c|}
\hline $\begin{array}{l}\text { Pengalaman } \\
\text { Menjadi guru }\end{array}$ & $\begin{array}{l}\text { Aspek } \\
\text { Kemelekan Sains }\end{array}$ & Skor \\
\hline \multirow[t]{3}{*}{$\begin{array}{l}\text { Kurang dari } 2 \\
\text { tahun }\end{array}$} & $\begin{array}{l}\text { Penguasaan konsep dasar } \\
\text { sains }\end{array}$ & 37 \\
\hline & Dampak sosial sains & 61 \\
\hline & $\begin{array}{l}\text { Pola pikir sains dan } \\
\text { teknologi }\end{array}$ & 40 \\
\hline \multirow{3}{*}{$\begin{array}{l}\text { Antara } \\
\text { sampai } \\
\text { tahun }\end{array}$} & $\begin{array}{l}\text { Penguasaan konsep dasar } \\
\text { sains }\end{array}$ & 40 \\
\hline & Dampak Sosial Sains & 47 \\
\hline & $\begin{array}{l}\text { Pola pikir sains dan } \\
\text { teknologi }\end{array}$ & 40 \\
\hline \multirow[t]{3}{*}{$\begin{array}{l}\text { Lebih dari } 5 \\
\text { tahun }\end{array}$} & $\begin{array}{l}\text { Penguasaan konsep dasar } \\
\text { sains }\end{array}$ & 49 \\
\hline & Dampak Sosial Sains & 60 \\
\hline & Pola pikir sains & 38 \\
\hline
\end{tabular}

\begin{tabular}{|l|l|l|}
\hline & teknologi & \\
\hline Rerata skor & 46 \\
\hline
\end{tabular}

Data hubungan antara pengalaman mengajar dan skor kemelekan inkuiri dapat dilihat pada Tabel 2 berikut ini.

Tabel 2. Tingkat Kemelekan Inkuiri

\begin{tabular}{|c|c|c|}
\hline $\begin{array}{l}\text { Pengalaman } \\
\text { Menjadi guru }\end{array}$ & $\begin{array}{l}\text { Aspek } \\
\text { Kemelekan Inkuiri }\end{array}$ & Skor \\
\hline \multirow{6}{*}{$\begin{array}{l}\text { Kurang dari } 2 \\
\text { tahun }\end{array}$} & Merumuskan masalah & 59 \\
\hline & Membuat inferensi & 67 \\
\hline & $\begin{array}{ll}\begin{array}{l}\text { Mengunakan } \\
\text { ruang-waktu }\end{array} & \text { relasi } \\
\end{array}$ & 56 \\
\hline & Merancang eksperimen & 63 \\
\hline & Menginterpretasi data & 54 \\
\hline & Mengambil kesimpulan & 53 \\
\hline \multirow{6}{*}{$\begin{array}{l}\text { Antara } 2 \\
\text { sampai } 5 \text { tahun }\end{array}$} & Merumuskan masalah & 44 \\
\hline & Membuat inferensi & 53 \\
\hline & $\begin{array}{l}\text { Mengunakan } \\
\text { ruang-waktu }\end{array}$ & 46 \\
\hline & Merancang eksperimen & 44 \\
\hline & Menginterpretasi data & 39 \\
\hline & Mengambil kesimpulan & 58 \\
\hline \multirow{6}{*}{$\begin{array}{l}\text { Lebih dari } 5 \\
\text { tahun }\end{array}$} & Merumuskan masalah & 63 \\
\hline & Membuat inferensi & 68 \\
\hline & $\begin{array}{ll}\text { Mengunakan } & \text { relasi } \\
\text { ruang-waktu }\end{array}$ & 60 \\
\hline & Merancang eksperimen & 53 \\
\hline & Menginterpretasi data & 62 \\
\hline & Mengambil kesimpulan & 65 \\
\hline Rerata skor & & 56 \\
\hline
\end{tabular}


Rendahnya skor science literacy dan inquiry literacy yang dimiliki oleh guru tentunya membawa dampak pada rendahnya kecakapan hidup (life skills) yang dimiliki oleh siswa. Dalam [3] disebutkan bahwa hasil riset PISA (Program for International Student Assessment), studi yang memfokuskan pada literasi bacaan, matematika, dan IPA (termasuk fisika) menunjukkan peringkat Indonesia baru bisa menduduki 10 besar terbawah dari 65 negara. Hasil Riset TIMSS (Trends in International Mathematics and Science Study) menunjukkan siswa Indonesia berada pada rangking amat rendah dalam kemampuan
(1) memahami informasi yang komplek, (2) teori, analisis dan pemecahan masalah, (3) pemakaian alat, prosedur dan pemecahan masalah dan (4) melakukan investigasi. Berdasarkan analisis hasil PISA 2009, ditemukan bahwa dari 6 (enam) level kemampuan yang dirumuskan di dalam studi PISA, hampir semua peserta didik Indonesia hanya mampu menguasai pelajaran sampai level 3 (tiga) saja, sementara negara lain yang terlibat di dalam studi ini banyak yang mencapai level 4 (empat), 5 (lima), dan 6 (enam). Hal ini ditunjukkan oleh Gambar 1 sebagai berikut.

\section{Refleksi dari Hasil PISA 2009}

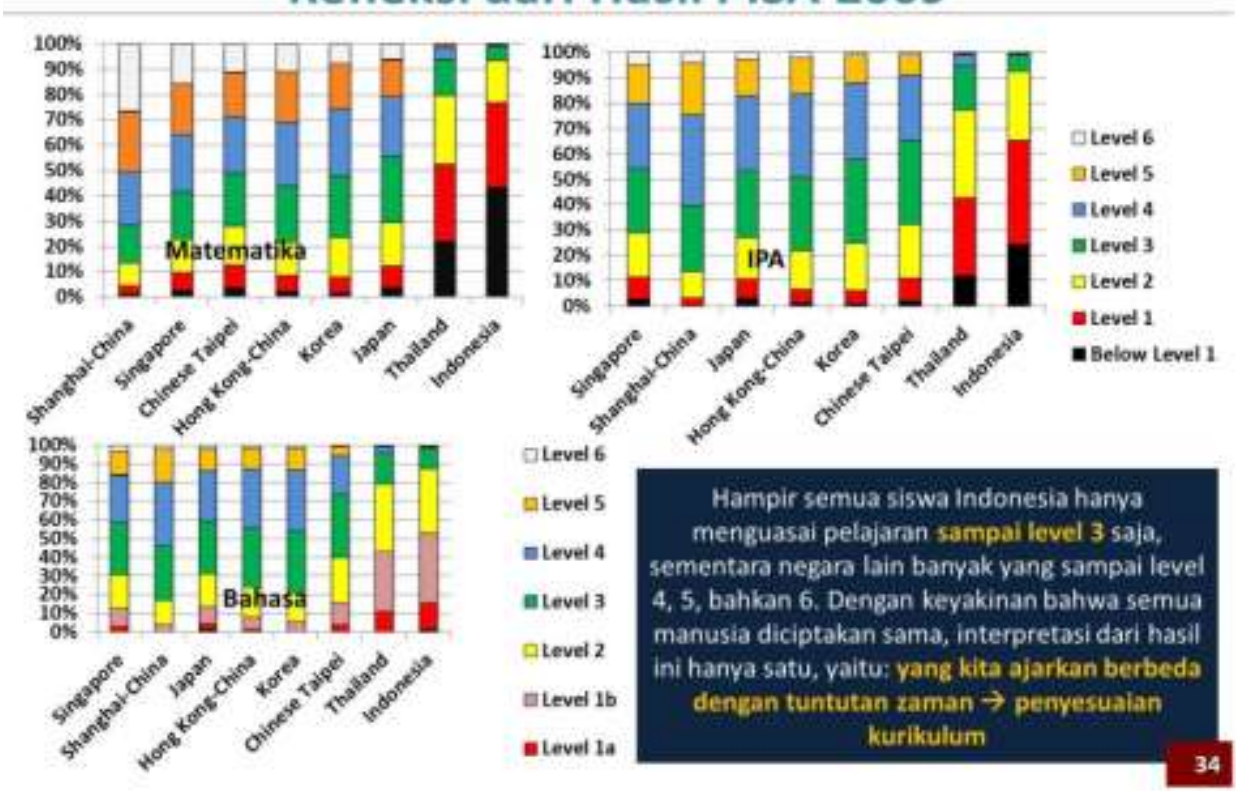

Gambar 1. Refleksi dari Hasil PISA

Analisis hasil TIMSS tahun 2007 dan 2011 di bidang IPA (termasuk fisika), menunjukkan bahwa lebih dari 95\% peserta didik Indonesia hanya mampu mencapai level menengah, sementara hampir $40 \%$ peserta didik Taiwan mampu mencapai level tinggi dan lanjut (advanced), sebagaimana ditunjukkan oleh Gambar 2.

Berdasarkan permasalahan pendidikan yang dikemukakan di atas, maka pemerintah maupun pemerhati pendidikan diharapkan dapat memfasilitasi upaya meningkatkan kecakapan hidup guru dan siswa di sekolah menengah. Kecakapan hidup siswa yang terdiri atas kecakapan personal, sosial, akademik, dan vokasional dapat dikembangkan melalui pembelajaran fisika berbasis aktivitas siswa. Bonwell \& Eison dalam [4] mendefinisikan belajar aktif sebagai metode pembelajaran yang melibatkan para siswa dalam proses pembelajaran. Singkatnya, pembelajaran aktif menuntut siswa untuk melakukan kegiatan belajar bermakna dan berpikir tentang apa yang mereka lakukan. Menurut [5], kecakapan personal dan sosial sering disebut sebagai kecakapan hidup yang bersifat umum (kecakapan hidup generik/general life skills). Kecakapan akademik dan vokasional sering disebut sebagai kecakapan hidup yang bersifat khusus (kecakapan hidup spesifik/specific life skills).

Dalam [6] dikatakan bahwa memasuki abad ke-21, kehidupan, secara global, sedang mengalami transisi dan perubahan yang signifikan. Diantara yang paling terkena dampaknya adalah remaja atau siswa sekolah menengah. Pengembangan kecakapan hidup menjadi sangat penting untuk kemajuan suatu Negara. Hasil penelitiannya menunjukkan bahwa terdapat hubungan yang positif antara kecakapan hidup (life skills) dan konsep diri siswa (self concept). Dengan kata lain, siswa yang dibekali dengan kecakapan hidup akan memiliki tingkat kepercayaan diri yang lebih tinggi. 


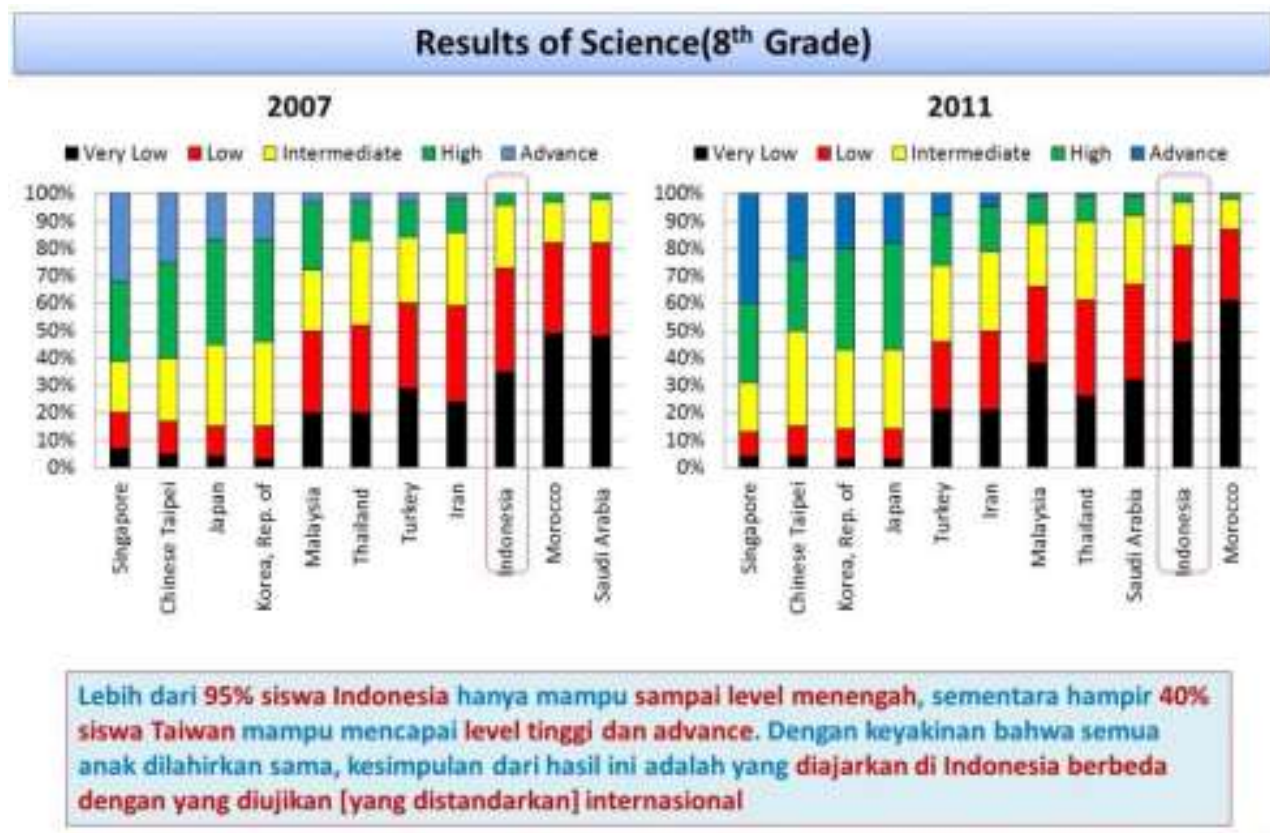

\section{Gambar 2. Refleksi dari Hasil TIMSS}

Kurikulum kecakapan hidup memainkan peran utama dalam memungkinkan siswa untuk menggunakan pengetahuan, sikap dan nilai-nilai ke dalam kemampuan pada apa yang harus dilakukan dan bagaimana melakukannya. Beberapa faktor yang mempengaruhi pelaksanaan kurikulum Kecakapan Hidup, yaitu: pendekatan mengajar, kurangnya konseptualisasi kecakapan hidup, sumber daya manusia yang terbatas, kurangnya pengawasan, persiapan guru masih kurang, kurangnya pilihan strategi belajar mengajar, terbatasnya penggunaan sumber daya pembelajaran, metode penilaian yang buruk, dan sikap negatif siswa terhadap kecakapan hidup. Pelaksanaan Pendidikan Kecakapan Hidup tergantung terutama pada kompetensi guru yang di sisi lain dipengaruhi juga oleh faktor-faktor ekstrinsik [7].

Menurut [8], pelaksanaan pembelajaran berbasis kecakapan hidup dapat dilakukan dengan mengintegrasikan aspek-aspek kecakapan hidup pada mata pelajaran di sekolah, salah satunya fisika. Permasalahan yang muncul dalam implementasi pembelajaran berbasis kecakapan hidup diantaranya adalah bagaimana merancang perangkat pembelajaran berbasis kecakapan hidup, bagaimana mengembangkan kegiatan pembelajaran berbasis kecakapan hidup dan bagaimana memahami aspekaspek kecakapan hidup dalam setiap mata pelajaran serta kesulitan dalam mengintegrasikan setiap aspekaspek kecakapan hidup dalam setiap pokok materi pelajaran sesuai dengan format yang tersedia.

Salah satu alternatif upaya untuk meningkatkan kecakapan hidup dimaksud adalah dengan penerapan model siklus belajar 5-E (learning cycle) dalam pembelajaran di sekolah. Dalam [9] disebutkan bahwa penerapan model siklus belajar 5-E dalam pembelajaran terdiri atas 5 tahapan yaitu: Engage, Explore, Explain, Elaborate, dan Evaluate. Menurut [10], model siklus belajar 5-E tidak hanya digunakan dalam pembelajaran sains (fisika) tetapi dapat pula diterapkan pada pembelajaran teknologi maupun matematika. Lima tahapan dalam model siklus belajar 5-E dirancang untuk memfasilitasi perubahan konseptual siswa.

Siklus belajar dapat diterapkan pada semua jenjang pendidikan, mulai dari sekolah dasar, menengah, bahkan di perguruan tinggi. Model pembelajaran sains learning cycle dengan metode eksperimen dapat meningkatkan hasil belajar siswa di Sekolah Dasar [11]. Implementasi model pembelajaran Learning Cycle 5E secara terpadu dengan permainan kartu Link and Match dapat meningkatkan kemampuan komunikasi siswa SMP [12]. Penerapan siklus belajar 5E disertai LKS dapat meningkatkan: (1) kualitas proses belajar siswa SMA yaitu minat belajar siswa meningkat dari siklus I menuju siklus II; (2) kualitas hasil belajar siswa SMA yaitu prestasi belajar kognitif siswa meningkat dari siklus I ke siklus II [13]. Model pembelajaran siklus belajar (learning cycle) 5E efektif untuk meningkatkan proporsi penurunan jumlah mahasiswa yang mengalami miskonsepsi di Perguruan Tinggi [14].

Tulisan ini akan membahas tentang pembelajaran fisika dengan model siklus belajar 5-E (Engage, Explore, Explain, Elaborate, Evaluate) sebagai upaya meningkatkan kecakapan hidup siswa. 


\section{Pembahasan}

\section{A. Pembelajaran Fisika}

Pembelajaran dapat didefinisikan sebagai proses interaksi antara siswa dengan lingkungannya sehingga terjadi perubahan prilaku siswa tersebut ke arah yang lebih baik. Proses pembelajaran akan selalu melibatkan tiga komponen pokok yakni: komponen pengirim pesan (guru), komponen penerima pesan (siswa) dan komponen pesan itu sendiri yang biasanya dalam bentuk materi pelajaran, termasuk fisika.

Fisika merupakan bagian dari sains yang pada hakikatnya adalah kumpulan pengetahuan, cara berpikir, dan penyelidikan. Fisika sebagai kumpulan pengetahuan dapat berupa fakta, konsep, prinsip, hukum, teori, dan model. Fisika sebagai cara berpikir merupakan aktivitas yang berlangsung di dalam pikiran orang yang berkecimpung di dalamnya karena adanya rasa ingin tahu dan hasrat untuk memahami fenomena alam. Fisika sebagai cara penyelidikan merupakan cara bagaimana informasi ilmiah diperoleh, diuji, dan divalidasikan. Dengan demikian, fisika harus dipandang sebagai suatu proses dan sekaligus produk. Oleh karena itu, dalam pembelajaran fisika kedua hal tersebut harus dijadikan pertimbangan dalam memilih strategi atau metode mengajar sehingga proses pembelajaran dapat berlangsung efektif dan efisien. Pada proses pembelajaran fisika secara konvensional, yang hanya mengandalkan pada olah pikir (minds-on), yang berarti memperlakukan fisika sebagai kumpulan pengetahuan (a body of knowledge), siswa cenderung hanya menguasai konsep-konsep fisika dengan sedikit bahkan tanpa diperolehnya keterampilan proses [15].

Tantangan dalam mengajar fisika adalah untuk menciptakan pengalaman yang melibatkan siswa dan bagaimana memfasilitasi siswa agar dapat memiliki kecakapan seperti mengamati, mengukur, mengklasifikasi, mengkomunikasikan, menyimpulkan, menggunakan bilangan, menggunakan hubungan ruang/waktu, bertanya, mengontrol dan memanipulasi variabel, membuat hipotesis, membuat definisi operasional variabel, membuat model, merancang eksperimen, dan menginterpretasi data [16]. Strategi yang digunakan oleh guru merupakan salah satu faktor yang berpengaruh terhadap prestasi akademik yang masih kurang pada matapelajaran fisika [17].

Di dalam kelas yang terpusat pada siswa peran guru adalah membantu siswa menemukan fakta, konsep, atau prinsip bagi diri mereka sendiri, bukan memberikan ceramah atau mengendalikan seluruh kelas. Dengan kata lain, peranan guru perlu bergeser dari menentukan apa yang harus dipelajari menjadi bagaimana menyediakan dan memperkaya pengalaman belajar siswa [18] dan [19]. Pandangan bahwa pembelajaran di sekolah haruslah berpusat pada aktivitas siswa juga diungkapkan oleh [20], dan [18] mengatakan bahwa strategi yang demikian disebut sebagai strategi konstruktivis (student centered instruction). Dalam hal ini, siswa harus membangun pengetahuan di dalam benaknya sendiri, guru dapat memberi siswa tangga yang dapat membantunya untuk mencapai tingkat pemahaman yang lebih tinggi.

\section{B. Model Siklus Belajar 5-E}

Pengembangan kemampuan siswa dalam berpikir dan bekerja ilmiah berlandaskan inkuiri dapat dilakukan dengan pengenalan pemahaman secara konseptual. Pemahaman secara konseptual ini dikembangkan dengan siklus belajar yang dilakukan secara rutin oleh guru. Lebih lanjut dikatakan bahwa dasar pemikiran model pembelajaran siklus belajar adalah pergeseran paradigma teacher-oriented ke student-oriented. Pendekatan pembelajaran yang digunakan dalam pembelajaran sains (fisika) seharusnya berorientasi pada siswa. Pembelajaran fisika seyogianya melibatkan siswa dalam penyelidikan yang berorientasi inkuiri, dengan interaksi antara siswa dengan guru dan siswa lainnya. Siswa membuat hubungan antara pengetahuan yang dimilikinya dengan pengetahuan ilmiah yang ditemukannya pada berbagai sumber, siswa menerapkan materi fisika untuk mengajukan pertanyaan, siswa menggunakan pengetahuannya dalam pemecahan masalah, perencanaan, membuat keputusan, diskusi kelompok, dan siswa memperoleh asesmen yang konsisten dengan suatu pendekatan yang aktif untuk belajar [21].

Menurut [9], siklus belajar (learning cycle) pertama kali dikembangkan oleh Robert Karplus pada tahun 1960 dalam program the Science Curriculum Improvement Study (SCIS). Siklus belajar menurut program ini terdiri dari tiga fase yaitu: discovery, concept invention, dan concept application. Pada tahun 1989, model siklus belajar dikembangkan menjadi model 5E oleh the Biological Sciences Curriculum Study (BSCS). Menurut [10], Perbandingan Fase Siklus Belajar Menurut SCIS dan BSCS ditunjukkan oleh Tabel 3 berikut ini.

Tabel 3. Perbandingan Fase Siklus Belajar Menurut SCIS dan BSCS

\begin{tabular}{|l|l|}
\hline \multicolumn{1}{|c|}{ SCIS } & \multicolumn{1}{c|}{ BSCS } \\
\hline & Engagement (fase baru) \\
\hline Exploration & $\begin{array}{l}\text { Exploration (diadaptasi } \\
\text { dari SCIS) }\end{array}$ \\
\hline $\begin{array}{l}\text { Invention (Term } \\
\text { Introduction) }\end{array}$ & $\begin{array}{l}\text { Explanation (diadaptasi } \\
\text { dari SCIS) }\end{array}$ \\
\hline $\begin{array}{l}\text { Discovery (Concept } \\
\text { Application) }\end{array}$ & $\begin{array}{l}\text { Elaboration (diadaptasi dari } \\
\text { SCIS) }\end{array}$ \\
\hline & Evaluation (fase baru) \\
\hline
\end{tabular}




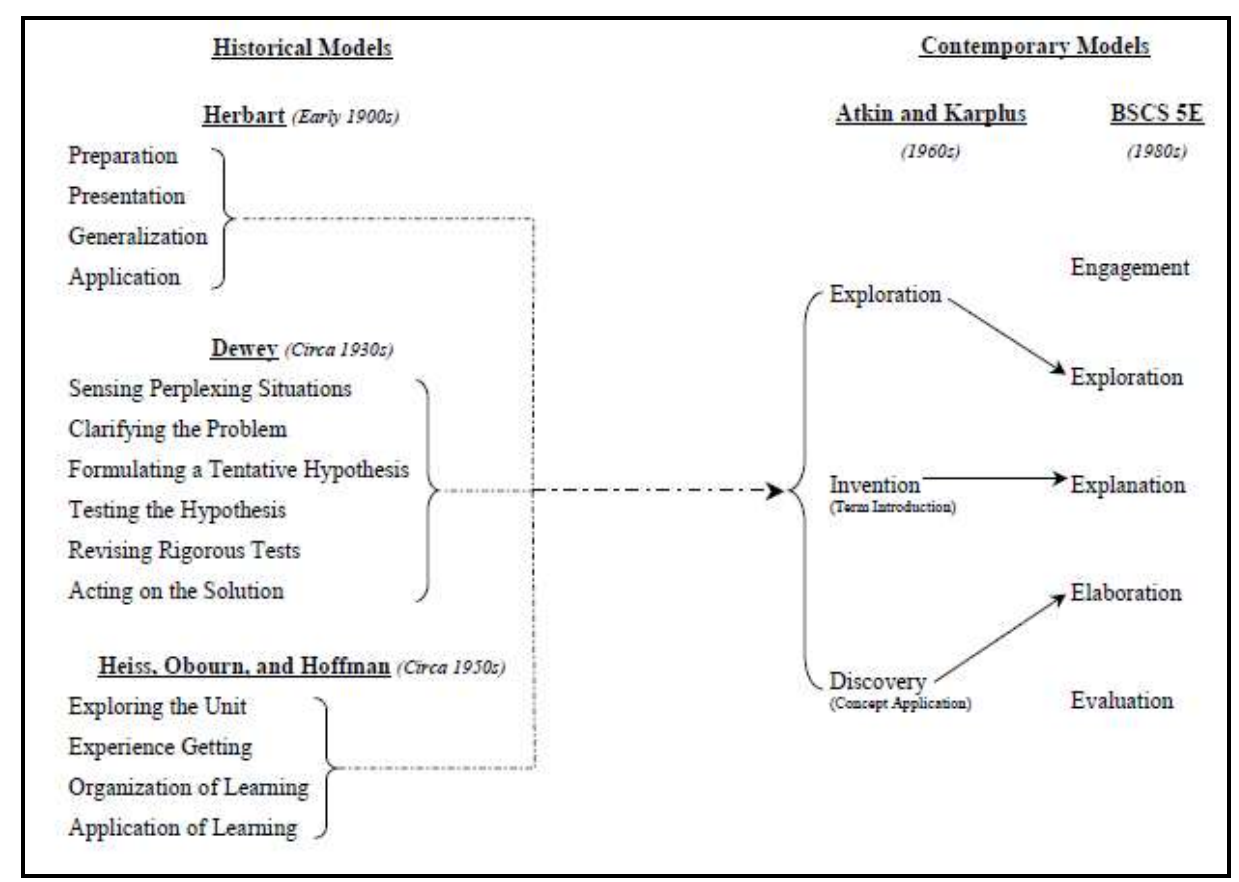

Gambar 3. Sejarah perkembangan siklus belajar

Menurut [10], sejarah perkembangan siklus belajar ditunjukkan Gambar 3. Fase model siklus belajar 5-E yang diadaptasi dari [9] dan [10] ditunjukkan dalam Tabel 4 sebagai berikut.

Tabel 4. Fase Pembelajaran Model Siklus Belajar 5-E

\begin{tabular}{|c|c|}
\hline Fase & Aktivitas Siswa \\
\hline Engage & $\begin{array}{l}\text { Mengajukan pertanyaan tentang benda, } \\
\text { mahkluk hidup, atau peristiwa } \\
\text { dikehidupan sehari-hari. }\end{array}$ \\
\hline Explore & $\begin{array}{lcr}\text { Merencanakan } & \text { dan } & \text { melakukan } \\
\text { penelitian sederhana } & \text { untuk } \\
\text { mengumpulkan data yang relevan. }\end{array}$ \\
\hline Explain & $\begin{array}{l}\text { Menggunakan data dan pengetahuan } \\
\text { ilmiah untuk } \\
\text { pemahamannya. }\end{array}$ \\
\hline Elaborate & $\begin{array}{l}\text { Mengembangkan strategi, konsep, } \\
\text { prinsip, dan pemahamannya menuju } \\
\text { masalah dan pertanyaan yang baru. }\end{array}$ \\
\hline Evaluate & $\begin{array}{l}\text { Mendemonstrasikan pengetahuan, } \\
\text { pemahaman, dan keterampilannya } \\
\text { menggunakan strategi inkuiri melalui } \\
\text { penilaian formatif formal maupun } \\
\text { informal. }\end{array}$ \\
\hline
\end{tabular}

Secara struktural, model siklus belajar 5 tahap ini lebih sesuai dengan struktur pembelajaran fisika yang terdiri dari kegiatan awal, inti dan penutup. Kesesuaian tahapan siklus belajar dan pembelajaran fisika dapat dilihat pada Tabel 5 di bawah ini [21].
Tabel 5. Kesesuaian Tahap Siklus Belajar dan Pembelajaran Fisika

\begin{tabular}{ll}
\hline Struktur Pembelajaran & $\begin{array}{l}\text { The 5 E Learning } \\
\text { Cycle }\end{array}$ \\
\hline Sains (Fisika) & Engagement \\
\hline Kegiatan Awal & Exploration \\
Kegiatan Inti & Explanation \\
& Elaboration \\
Kegiatan Penutup & Evaluation \\
\hline
\end{tabular}

Dalam [21] dikatakan bahwa aktivitas dalam model siklus belajar tersebut bersifat fleksibel tetapi urutan fase belajarnya bersifat tetap. Format belajar dalam siklus belajar dapat berubah tetapi urutan setiap fase tersebut tidak dapat diubah atau dihapus, karena jika urutannya diubah atau fasenya dihapus maka model yang dimaksud tidak berupa siklus belajar.

Hasil penelitian [22] menyimpulkan bahwa model siklus belajar telah terbukti efektif dalam membantu siswa membentuk konsep dan sistem konseptual serta mengembangkan pola penalaran yang lebih efektif, terutama karena memungkinkan siswa untuk menggunakan penalaran (jika / kemudian / karena itu) untuk menguji ide-ide mereka sendiri yang berpartisipasi dalam proses konstruksi pengetahuan. Berdasarkan penelitian [10], menunjukkan bahwa penerapan siklus belajar (learning cycle) berpengaruh positif terhadap penguasaan materi pelajaran, penalaran ilmiah, dan sikap siswa terhadap sains. Hasil penelitian [23] menunjukkan bahwa pembelajaran fisika pada materi pokok Cahaya dengan model 5E mampu mengembangkan keterampilan berpikir kritis dan sikap siswa terhadap sains. Siswa dapat merumuskan masalah, mengamati, menganalisis, menyajikan hasil, dan 
mengkomunikasikan hasil karya melalui diskusi di kelas.

\section{Kecakapan Hidup Siswa}

World Health Organization (WHO) dalam [6] mendefinisikan kecakapan hidup sebagai kemampuan untuk perilaku adaptif dan positif yang memungkinkan individu untuk secara efektif menangani tuntutan dan tantangan hidup sehari-hari. Lebih lanjut dijelaskan bahwa United Nations International Children's Emergency Fund (UNICEF) mendefinisikan kecakapan hidup sebagai perubahan perilaku atau pendekatan pembangunan perilaku yang dirancang untuk mengatasi keseimbangan tiga bidang: Pengetahuan, sikap dan keterampilan. Dengan kata lain, kecakapan hidup adalah keterampilan yang diperlukan untuk hidup sukses.

Dalam [5] dan [24], diuraikan bahwa kecakapan hidup terdiri atas kecakapan hidup yang bersifat umum (General life skills) dan kecakapan hidup yang bersifat khusus (Specific life skills). Kecakapan hidup yang bersifat umum terdiri dari kecakapan personal dan sosial, sedangkan kecakapan hidup yang bersifat spesifik terdiri dari kecakapan akademik dan vokasional. Dengan demikian dapat dikatakan bahwa kecakapan hidup (life skills) merupakan salah satu kata kunci dalam pengembangan pendidikan baik dalam nuansa pendidikan akademik (academic skills) maupun pendidikan yang bersifat kejuruan (vocational skills).

Kecakapan hidup generik atau kecakapan yang bersifat umum, adalah kecakapan untuk menguasai dan memiliki konsep dasar keilmuan. Kecakapan hidup generik berfungsi sebagai landasan untuk belajar lebih lanjut dan bersifat transferable, sehingga memungkinkan untuk mempelajari kecakapan hidup lainnya. Kecakapan hidup generik meliputi:

\section{a) Kecakapan Personal (Personal Skill), yakni :}

\section{(1) Kecakapan Mengenal Diri (Self-Awarness Skill)}

Kecakapan mengenal diri meliputi kesadaran sebagai makhluk Tuhan, kesadaran akan eksistensi diri, dan kesadaran akan potensi diri. Kecakapan mengenal diri pada dasarnya merupakan penghayatan diri sebagai makhluk Tuhan, makhluk sosial, bagian dari lingkungan, serta menyadari dan mensyukuri kelebihan dan kekurangan yang dimiliki, sekaligus meningkatkan diri agar bermanfaat bagi diri sendiri dan lingkungannya. Walaupun mengenal diri lebih merupakan sikap, namun diperlukan kecakapan untuk mewujudkannya dalam perilaku keseharian. Mengenal diri akan mendorong seseorang untuk beribadah sesuai agamanya, berlaku jujur, bekerja keras, disiplin, terpercaya, toleran terhadap sesama, suka menolong serta memelihara lingkungan. Sikap-sikap tersebut tidak hanya dapat dikembangkan melalui pelajaran agama dan kewarganegaraan, tetapi melalui pelajaran kimia sikap jujur (contoh: tidak memalsukan data hasil praktikum) dan disiplin (contoh: tepat waktu, taat aturan yang disepakati, dan tata tertib laboratorium) tetap dapat dikembangkan.

\section{(2) Kecakapan Berpikir (Thinking Skill)}

Kecakapan berpikir merupakan kecakapan menggunakan pikiran atau rasio secara optimal. Kecakapan berpikir meliputi :

- Kecakapan Menggali dan Menemukan Informasi (Information Searching); kecakapan ini memerlukan keterampilan dasar seperti membaca, menghitung, dan melakukan observasi.

- Kecakapan Mengolah Informasi (Information Processing); Informasi yang telah dikumpulkan harus diolah agar lebih bermakna. Mengolah informasi artinya memproses informasi tersebut menjadi suatu kesimpulan. Untuk memiliki kecakapan mengolah informasi ini diperlukan kemampuan membandingkan, membuat perhitungan tertentu, membuat analogi sampai membuat analisis sesuai informasi yang diperoleh.

- Kecakapan Mengambil Keputusan (Decision Making); Setelah informasi diolah menjadi suatu kesimpulan, tahap berikutnya adalah pengambilan keputusan. Dalam kehidupan sehari-hari, seseorang selalu dituntut untuk membuat keputusan betapun kecilnya keputusan tersebut. Karena itu siswa perlu belajar mengambil keputusan dan menangani resiko dari pengambilan keputusan tersebut.

- Kecakapan Memecahkan Masalah (Creative Problem Solving Skill); Pemecahan masalah yang baik tentu berdasarkan informasi yang cukup dan telah diolah. Siswa perlu belajar memecahkan masalah sesuai dengan tingkat berpikirnya sejak dini. Selanjutnya untuk memecahkan masalah ini dituntut kemampuan berpikir rasional, berpikir kreatif, berpikir alternatif, berpikir sistem dan sebagainya. Karena itu pola-pola berpikir tersebut perlu dikembangkan di sekolah, dan selanjutnya diaplikasikan dalam bentuk pemecahan masalah.

b) Kecakapan Sosial (Social Skill) terdiri atas :

\section{(1) Kecakapan Berkomunikasi}

Yang dimaksud berkomunikasi bukan sekedar menyampaikan pesan, tetapi komunikasi dengan empati. Empati, sikap penuh pengertian, dan seni komunikasi dua arah perlu dikembangkan dalam keterampilan berkomunikasi agar isi pesannya sampai dan disertai kesan baik yang dapat menumbuhkan hubungan harmonis. Berkomunikasi dapat melalui lisan atau tulisan. Untuk komunikasi lisan, kemampuan mendengarkan dan menyampaikan gagasan secara lisan perlu dikembangkan. 
Berkomunikasi lisan dengan empati berarti kecakapan memilih kata dan kalimat yang mudah dimengerti oleh lawan bicara. Kecakapan ini sangat penting dan perlu ditumbuhkan dalam pendidikan. Berkomunikasi melalui tulisan juga merupakan hal yang sangat penting dan sudah menjadi kebutuhan hidup. Kecakapan menuangkan gagasan melalui tulisan yang mudah dipahami orang lain, merupakan salah satu contoh dari kecakapan berkomunikasi tulisan.

\section{(2) Kecakapan Bekerjasama (Collaboration Skill)}

Sebagai makhluk sosial, dalam kehidupan seharihari manusia akan selalu memerlukan dan bekerjasama dengan manusia lain. Kecakapan bekerjasama bukan sekedar "bekerja bersama" tetapi kerjasama yang disertai dengan saling pengertian, saling menghargai, dan saling membantu. Kecakapan ini dapat dikembangkan dalam semua mata pelajaran, misalnya mengerjakan tugas kelompok, karyawisata, maupun bentuk kegiatan lainnya.

Kecakapan hidup spesifik terkait dengan bidang pekerjaan (occupational) atau bidang kejuruan (vocational) tertentu. Jadi, kecakapan hidup spesifik diperlukan seseorang untuk menghadapi masalah bidang tertentu. Kecakapan hidup spesifik ini meliputi:

\section{a) Kecakapan Akademik (Academic Skill)}

Kecakapan akademik disebut juga kecakapan intelektual atau kemampuan berpikir ilmiah dan merupakan pengembangan dari kecakapan berpikir. Kecakapan akademik sudah mengarah ke kegiatan yang bersifat akademik atau keilmuan. Kecakapan ini penting bagi orang yang menekuni bidang pekerjaan yang menekankan pada kecakapan berpikir. Oleh karena itu kecakapan ini harus mendapatkan penekanan mulai jenjang Sekolah Menengah pertama dan terlebih pada program akademik di universitas. Kecakapan akademik ini meliputi antara lain kecakapan: mengidentifikasi variabel, menjelaskan hubungan variabel-variabel, merumuskan hipotesis, merancang dan melakukan percobaan.

\section{b) Kecakapan (Vocational Skill)}

Vokasional/Kejuruan

Kecakapan vokasional disebut juga kecakapan kejuruan, yaitu kecakapan yang dikaitkan dengan bidang pekerjaan tertentu yang terdapat di masyarakat. Kecakapan ini lebih cocok untuk siswa yang akan menekuni pekerjaan yang lebih mengandalkan keterampilan psikomotor. Jadi kecakapan ini lebih cocok bagi siswa Sekolah Menengah Kejuruan, kursus keterampilan atau program diploma. Kecakapan vokasional meliputi :

- Kecakapan Vocasional Dasar (Basic Vocational Skill), antara lain: kecakapan melakukan gerak dasar, menggunakan alat sederhana, atau kecakapan membaca gambar.

- Kecakapan Vocational Khusus (Occupational Skill), kecakapan ini memiliki prinsip dasar menghasilkan barang atau jasa.

Program pendidikan berorientasi kecakapan hidup melalui pendekatan berbasis luas atau yang dikenal dengan istilah Broad Base Education (BBE) sangat memungkinkan untuk dilaksanakan pada setiap jenis dan jenjang pendidikan. Selain tidak mengubah sistem kurikulum yang ada, program ini tidak menambah beban mata pelajaran baru, melainkan hanya mengubah orientasi program pembelajaran [25].

Menurut [24], pembelajaran kecakapan hidup memerlukan reorientasi pendidikan dari subjectmatter oriented menjadi life-skill oriented. Kecakapan hidup yang harus dimiliki siswa hendaknya termuat di dalam pengalaman belajar yang dipilih guru. Dalam memilih pengalaman belajar perlu dipertimbangkan kecakapan hidup apa yang akan dikembangkan pada setiap kompetensi dasar. Untuk itu diperlukan analisis kecakapan hidup setiap kompetensi dasar. Pengalaman belajar merupakan kegiatan fisik dan mental yang dilakukan siswa dalam berinteraksi dengan bahan ajar. Pengalaman belajar dilakukan oleh siswa untuk menguasai kompetensi dasar yang telah ditentukan. Dalam pelaksanaannya, pembelajaran kecakapan hidup ini: tidak dikemas dalam bentuk mata pelajaran baru; tidak dikemas dalam materi tambahan yang disisipkan dalam mata pelajaran; tidak memerlukan tambahan alokasi waktu pembelajaran di kelas; tidak memerlukan jenis buku baru; tidak memerlukan tambahan guru baru; dapat diterapkan dengan menggunakan kurikulum apapun.

Pada Kurikulum 2006 (KTSP) dalam Mata pelajaran sains (fisika) di kelas VII Semester 1, terdapat Standar Kompetensi: 3. Memahami wujud zat dan perubahannya, dan Kompetensi Dasar: 3.2 Mendeskripsikan konsep massa jenis dalam kehidupan sehari-hari, serta Materi Pokok: Massa Jenis Benda. Pengalaman belajar yang dilakukan oleh siswa untuk menguasai kompetensi dasar dimaksud dan analisis kecakapan hidup ditunjukkan pada Tabel 6 berikut ini.

Tabel 6. Pengalaman Belajar dan Life Skills

\begin{tabular}{ll}
\hline Pengalaman Belajar & Life skills \\
\hline Melakukan percobaan & Identifikasi variabel \\
untuk menentukan & Menghubungkan variabel \\
hubungan antara & Merumuskan hipotesis \\
massa dan volume & Merancang percobaan \\
terhadap massa jenis & Melakukan percobaan \\
suatu zat & Mengolah informasi \\
& Memecahkan masalah \\
& Mengambil keputusan \\
& Komunikasi lisan dan \\
& tulisan \\
\hline
\end{tabular}


Pada Kurikulum 2013, dalam silabus matapelajaran Fisika (Peminatan Matematika dan Ilmu Alam) untuk satuan pendidikan SMA, kelas X terdapat Kompetensi Inti (KI) sebagai berikut. KI 1: Menghayati dan mengamalkan ajaran agama yang dianutnya; KI 2: Menghayati dan mengamalkan perilaku jujur, disiplin, tanggungjawab, peduli (gotong royong, kerjasama, toleran, damai), santun, responsif dan pro-aktif dan menunjukkan sikap sebagai bagian dari solusi atas berbagai permasalahan dalam berinteraksi secara efektif dengan lingkungan sosial dan alam serta dalam menempatkan diri sebagai cerminan bangsa dalam pergaulan dunia; KI 3: Memahami, menerapkan, menganalisis pengetahuan faktual, konseptual, prosedural berdasarkan rasa ingintahunya tentang ilmu pengetahuan, teknologi, seni, budaya, dan humaniora dengan wawasan kemanusiaan, kebangsaan, kenegaraan, dan peradaban terkait penyebab fenomena dan kejadian, serta menerapkan pengetahuan prosedural pada bidang kajian yang spesifik sesuai dengan bakat dan minatnya untuk memecahkan masalah; KI 4: Mengolah, menalar, dan menyaji dalam ranah konkret dan ranah abstrak terkait dengan pengembangan dari yang dipelajarinya di sekolah secara mandiri, dan mampu menggunakan metoda sesuai kaidah keilmuan.

Salah satu materi pembelajaran untuk kelas $X$ adalah Pengukuran yang terdiri dari beberapa sub materi yaitu: Ketelitian (akurasi) dan ketepatan (presisi); Penggunaan Alat Ukur; Kesalahan pengukuran; Penggunaan angka penting. Kompetensi Dasar yang bersesuaian dengan Kompetensi Inti tersebut di atas adalah: 1.1 Bertambah Keimanannya dengan menyadari hubungan keteraturan dan kompleksitas alam dan jagad raya terhadap kebesaran Tuhan yang menciptakannya; 1.2 Menyadari kebesaran Tuhan yang mengatur karakteristik fenomena gerak, fluida kalor dan optik; 2.1 Menunjukkan perilaku ilmiah (memiliki rasa ingin tahu; objektif; jujur; teliti; cermat; tekun; hati-hati; bertanggung jawab; terbuka; kritis; kreatif; inovatif dan peduli lingkungan) dalam aktivitas sehari-hari sebagai wujud implementasi sikap dalam melakukan percobaan , melaporkan, dan berdiskusi; 2.2 Menghargai kerja individu dan kelompok dalam aktivitas sehari sebagai wujud implementasi sikap dalam melakukan percobaan dan berdiskusi; 3.1 Memahami hakikat fisika dan prinsip-prinsip pengukuran (ketepatan, ketelitian, dan aturan angka penting); 4.1 Menyajikan hasil pengukuran besaran fisis dengan menggunakan peralatan dan teknik yang tepat untuk penyelidikan ilmiah.

Pengalaman belajar yang dilakukan oleh siswa SMA untuk menguasai kompetensi dasar pada kelas $\mathrm{X}$ dengan materi pembelajaran "Pengukuran" tersebut di atas dan analisis kecakapan hidup adalah sebagai berikut.

\section{- Mengamati:}

- Membuat daftar (tabel) nama besaran, alat ukur, cara mengukur, dan satuan yang digunakan secara individu, termasuk yang berlaku di daerah setempat (misalnya: untuk ukuran massa: mayam di Sumatera Utara, untuk ukuran panjang: tumbak di Jawa Barat).

- Mengamati beberapa alat ukur panjang, massa dan waktu yang ada di sekitar(mistar milimeter, jangka sorong, mikrometer, neraca lengan, neraca pegas, dan stopwatch) dan menemukan cara bagaimana alat tersebut bekerja/digunakan.

\section{- Menanyakan:}

- Menanyakan tentang hakikat fisika dan prinsip-prinsip pengukuran (ketepatan, ketelitian, dan aturan angka penting) dalam proses penyelidikan ilmiah.

- Menanyakan aspek ketelitian, ketepatan, dan keselamatan kerja, serta alat yang digunakan dalam mengukur.

\section{- Melakukan Eksperimen:}

- Mendiskusikan hakikat fisika dan prinsipprinsip pengukuran (ketepatan, ketelitian, dan aturan angka penting) dalam proses penyelidikan ilmiah.

- Mendiskusikan cara menggunakan alat ukur, cara mebaca skala, dan cara menuliskan hasil pengukuran.

- Mengukur masa jenis suatu benda misalnya kelereng dan batu kerikil (dilakukan berulang dengan ukuran beda dan jenis yang sama) secara berkelompok dengan menggunakan neraca, jangka sorong atau mikrometer, dan gelas ukur.

- Menerapkan aspek ketelitian, ketepatan, dan keselamatan kerja dalam mengukur.

\section{- Mengasosiasi:}

- Mengolah data hasil pengukuran berulang (diberikan oleh guru) dalam bentuk penyajian data, membuat grafik, menginterpretasi data dan grafik, dan menghitung kesalahan, serta menyimpulkan hasil interpretasi data.

\section{- Mengomunikasikan:}

- Membuat laporan tertulis dan mempresentasikan hasil pengukuran. 


\section{Pembelajaran Fisika dengan Model Siklus Belajar 5-E}

Pembelajaran merupakan proses yang menggabungkan pekerjaan dengan pengalaman. Apa yang dikerjakan orang di dunia menjadikan pengalaman baginya. Pengalaman tersebut akan menambah keterampilan, pengetahuan, atau pemahaman yang mencerminkan nilai yang dalam. Pembelajaran yang efektif akan mendorong kea rah perubahan, pengembangan serta meningkatkan hasrat untuk belajar. Pembelajaran tidak hanya menghasilkan atau membuat sesuatu, tetapi juga menyesuaikan, memperluas, dan memperdalam pengetahuan [26].

Pembelajaran pada dasarnya tidak hanya mempelajari tentang konsep, teori, dan fakta tetapi juga aplikasi dalam kehidupan sehari-hari. Dengan demikian, materi pembelajaran tidak hanya tersusun atas hal-hal sederhana yang bersifat hafalan dan pemahaman, tetapi juga tersusun atas materi yang kompleks yang memerlukan analisis, aplikasi, dan sintesis. Untuk itu, guru harus bijaksana dalam menentukan suatu model yang sesuai sehingga tercipta kondisi kelas yang kondusif agar proses pembelajaran dapat berlangsung sesuai dengan tujuan yang diharapkan [27]. Salah satu model pembelajaran yang dapat dijadikan alternatif bagi guru untuk mencapai tujuan pembelajaran, termasuk dalam pelajaran fisika, adalah model siklus belajar 5-E.

Hal- hal yang berkaitan erat dengan pembelajaran fisika di sekolah adalah elemen-elemen pokok dalam pembelajaran itu sendiri seperti: bahan dan aktivitas yang menarik bagi siswa, terbentuk pola pikir jika... dan... maka..., munculnya jawaban atau cara yang lebih efektif, munculnya uraian, prakiraan atau data baru, tersedianya kesempatan untuk memeriksa sejauh mana konsep baru dapat diterapkan dalam konteks lain, sifat khas pelajaran, sifat khas perilaku siswa, dan sifat khas perilaku guru. Dalam mendesain pembelajaran disarankan untuk meningkatkan pengetahuan konsep dan keterampilan berpikir dengan memperhatikan elemen-elemen tersebut. Demi tercapainya pembelajaran yang efektif perlu dimonitor pelaksanaannya melalui beberapa pertanyaan mengungkap sifat-sifat khas pelajaran dan perilaku siswa dan guru sebagai penginvestigasi kegiatan siswa oleh guru itu sendiri atau oleh orang lain, misalnya teman sejawat dan kepala sekolah [15].

Beberapa pertanyaan yang dapat digunakan untuk mengidentifikasi sifat khas pelajaran dimaksud yaitu: 1) Apakah pelajaran telah menggunakan bahan-bahan dan aktivitas-aktivitas yang menarik bagi siswa?; 2) Apakah pelajaran telah menggunakan bahan-bahan dan aktivitas-aktivitas yang membuat siswa untuk berpikir, bertanya, dan mendiskusikan maknanya?; 3) Apakah pertanyaan telah memberi kesempatan melakukan investigasi yang menumbuhkan inisiatif individu siswa?; 4) Apakah materi pelajaran tepat sesuai dengan tingkat perkembangan mental anak?; 5) Apakah pelajaran menyertakan konsep atau konsepkonsep dasar untuk mengembangkan pemahaman atau teori-teori fisika yang harus ditanamkan pada siswa?; 6) Apakah alat bantu pembelajaran, video, komputer, dan lain-lainnya seefektif alat bantu atau tambahantambahan yang digunakan ketika siswa melakukan investigasi?

Melalui monitoring, kegiatan yang dilakukan siswa dapat dimonitor oleh guru melalui identifikasi sifat khas perilaku siswa dengan menjawab beberapa pertanyaan seperti: 1) Apakah siswa melakukan pengamatan atau pengumpulan informasi yang dapat menimbulkan rasa keingintahuannya melalui bertanya?; 2) Apakah siswa menyusun hipotesis, teori, dan ramalan yang membantu siswa dalam menjawab pertanyaan?; 3) Apakah siswa menganalisis, menginterpretasi dan mengevaluasi data sendiri dalam kelompok atau sebagai suatu kelas dengan bimbingan guru?; 4) Apakah kesimpulan yang diajukan kelas berdasarkan fakta perolehan siswa sendiri atau oleh dominasi guru?

Seperti halnya dalam mengidentifikasi sifat khas perilaku siswa, maka mengidentifikasi sifat khas perilaku guru, dapat memonitor kegiatan yang dilakukan guru maupun diri kita sendiri (self monitoring) dengan menjawab beberapa pertanyaan yakni: 1) Ketika investigasi berlangsung, apakah guru berperan sebagai mitra penginvestigasi?; 2) Apakah guru berperan sebagai sekretaris kelas ketika data disusun untuk dianalisis?; 3) Apakah istilah-istilah baru dikenalkan setelah siswa memiliki cukup pengalaman langsung dengan bahan, kejadian, atau situasi yang memungkinkan mereka untuk memperluas presentasinya?; 4) Apakah guru menyiapkan bahan-bahan tambahan, pengalaman dan kejadian yang memperbesar, memperbaiki, dan memperkuat istilah yang telah dikenalkan sebelumnya?; 5) Apakah guru menguasai kelas dengan kalem, terpisah, sendiri, dan menunjukkan kepada siswa yang melakukan kesalahan?; 6) Apakah guru tampil percaya diri, tenang, dan bersahabat?

Cara terbaik untuk memahami karakteristikkarakteristik tersebut di atas dapat dipadukan dalam pembelajaran adalah dengan mempertimbangkan penggunaannya dalam topik atau materi pembelajaran tertentu, misalnya dalam penerapan model siklus belajar 5-E.

Petunjuk mengajar bagi guru dalam menggunakan model siklus belajar 5-E sebagai berikut [21]. Pada fase pendahuluan, guru dapat menggali pengetahuan awal siswa dengan menfokuskan perhatian dan minat siswa terhadap topik yang dibahas, memunculkan pertanyaan dan memperoleh respons dari siswa. Fase ini juga berguna untuk mengidentifikasi miskonsepsi atau salah konsep dalam pemahaman siswa. Pada saat menggali pengetahuan awal, guru dapat mengajukan 
masalah yang bertentangan. Misal, dengan demonstrasi benda A dan benda B yang memiliki massa berbeda dijatuhkan dari ketinggian yang sama. Pertanyaan yang dapat diajukan: "Benda manakah yang jatuh lebih dahulu ke lantai?" Berdasarkan demonstrasi tersebut siswa diharapkan memiliki jawaban yang berbeda dengan siswa lain sehingga menimbulkan konflik kognitif pada siswa. Dari respons siswa, guru dapat mengetahui pemahaman awal siswa tentang konsep yang dibahas sebelum pembelajaran.

Pada fase eksplorasi, siswa belajar melalui aksi dan reaksi mereka sendiri dalam situasi baru. Siswa mengeksplorasi materi dan gagasan baru dengan bimbingan minimal dari guru. Pengalaman baru memunculkan pertanyaan dan masalah yang tidak dapat dipecahkan dengan gagasan-gagasan siswa yang sudah ada. Fase eksplorasi memberikan kesempatan pada siswa untuk menyuarakan gagasan-gagasan yang bertentangan, yang dapat menimbulkan perdebatan dan analisis dari alasan munculnya gagasan mereka. Analisis tersebut dapat mengarahkan cara diskusi untuk menguji gagasan lainnya melalui prediksi. Eksplorasi juga dapat membawa siswa pada identifikasi suatu pola keteraturan dalam fenomena yang diteliti. Selama fase eksplorasi, siswa diberi kesempatan untuk bekerjasama dengan siswa lainnya tanpa instruksi dari guru melalui kegiatan diskusi.

Pada fase eksplanasi, kegiatan diawali dengan pengenalan konsep baru yang digunakan pada polapola yang diperoleh pada fase eksplorasi. Konsep baru tersebut dapat diperkenalkan oleh guru, melalui buku bacaan, film atau media lainnya. Selama fase eksplanasi guru memotivasi siswa untuk menjelaskan konsep yang dibahas dengan kata-kata sendiri, mengajukan fakta dan klarifikasi terhadap penjelasannya, dan mendengarkan secara kritis penjelasan siswa. Fase eksplanasi selalu mengikuti fase eksplorasi dan berkaitan langsung dengan pola yang ditemukan selama kegiatan eksplorasi.

Fase berikutnya adalah elaborasi atau dapat disebut juga aplikasi konsep. Pada fase ini siswa menerapkan konsep atau keterampilan pada situasi baru. Fase ini memberikan kesempatan bagi siswa untuk menggunakan konsep-konsep yang telah diperkenalkan untuk menyelidiki konsep-konsep tersebut lebih lanjut. Penerapan konsep diarahkan pada kehidupan sehari-hari.

Fase terakhir adalah evaluasi yang dilakukan pada seluruh pengalaman belajar siswa. Aspek yang dievaluasi pada fase ini adalah pengetahuan atau keterampilan, aplikasi konsep, dan perubahan proses berpikir siswa. Fase evaluasi juga memberikan kesempatan kepada siswa untuk menilai cara belajarnya, mengevaluasi kemajuan belajar dan proses pembelajaran. Evaluasi dapat dilakukan secara tertulis pada akhir pembelajaran atau secara lisan berupa pertanyaan selama pembelajaran berlangsung.

Hasil penelitian [28] menemukan bahwa siswa pada kelas eksperimen yang diajar menggunakan model siklus belajar 5-E (pembelajaran berbasis inkuiri) memiliki prestasi belajar yang jauh lebih tinggi dibandingkan dengan siswa pada kelas kontrol dengan model pembelajaran konvensional. Penelitian tersebut mengambil subyek siswa yang berusia antara 14-16 tahun. Peningkatan hasil belajar siswa yang dimaksud meliputi aspek pengetahuan, penalaran, dan argumentasi. Distribusi Bivariat Pretest-Posttest Kelas Eksperimen Dan Kelas Kontrol dalam penelitian tersebut dapat dilihat pada Gambar 4 sebagai berikut.

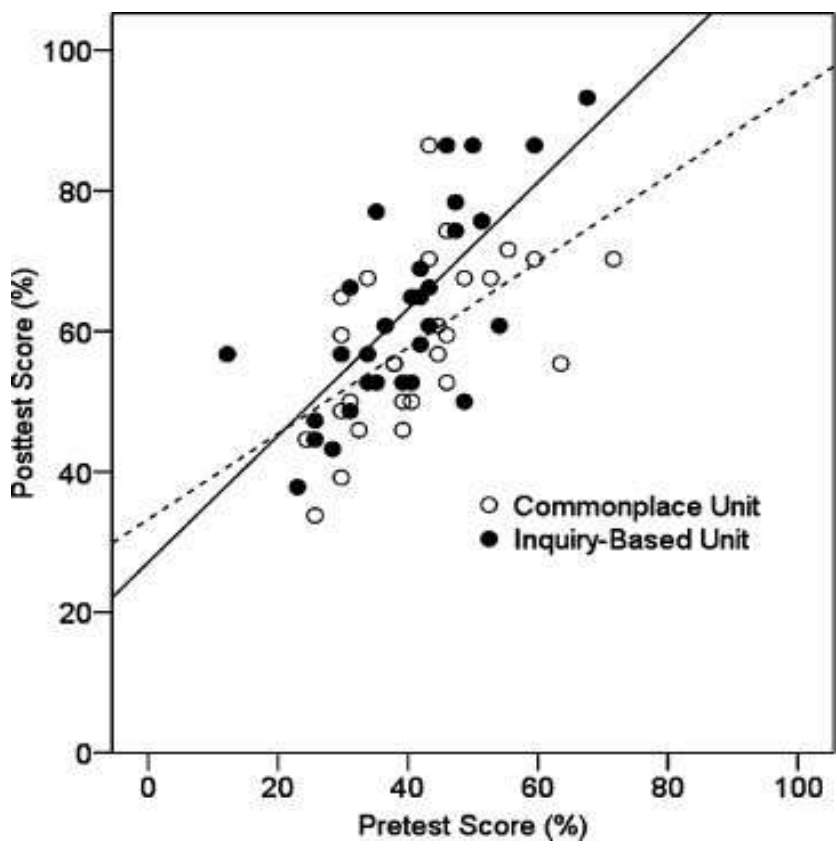

Gambar 4. Distribusi Bivariat Pretest-Posttest Kelas Eksperimen Dan Kelas Kontrol

Hasil penelitian [11] mengungkapkan bahwa terjadi peningkatan nilai rata-rata siswa dari siklus I sebesar 60,50 menjadi 80,25 pada siklus II. Dari 40 siswa SD, sudah banyak siswa yang tuntas dalam pembelajaran dengan model siklus belajar 5-E yaitu 35 anak $(87,50 \%)$ sudah tuntas dan yang belum tuntas sebanyak 5 anak (12,50\%). Peningkatan hasil belajar siswa tersebut ditunjukkan oleh Gambar 5 berikut ini. 


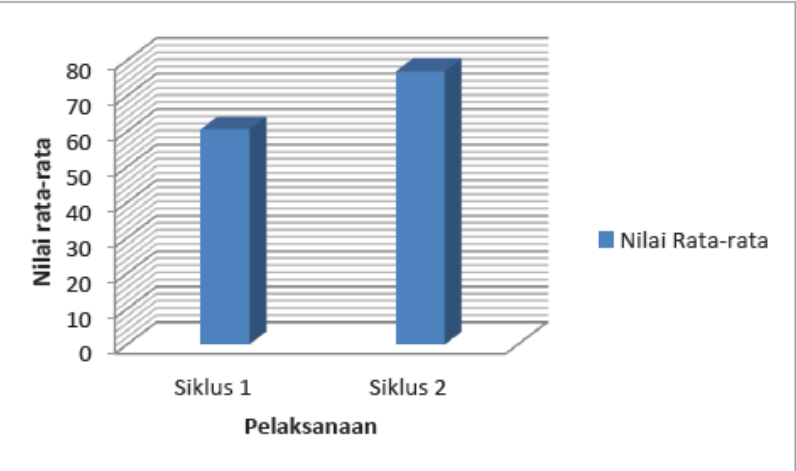

Gambar 5. Peningkatan Hasil Belajar Siswa SD

Hasil penelitian [12] mengungkapkan bahwa, penggunaan model pembelajaran Learning Cycle secara terpadu dengan kartu permainan Link and Match mampu meningkatkan kemampuan komunikasi siswa SMP. Melalui observasi selama berlangsungnya proses pembelajaran menunjukkan perubahan kemampuan komunikasi yang nyata pada siswa. Peningkatan kemampuan komunikasi siswa dalam pembelajaran berdasarkan perbandingan antara kondisi pra siklus dengan setelah diterapkannya model pembelajaran menggunakan model pembelajaran Learning Cycle 5-E. Peningkatan yang belum menampakkan hasil memuaskan terjadi selama proses pembelajaran pada siklus I. Peningkatan kemampuan komunikasi yang masih rendah tersebut antara lain tampak dalam usaha siswa yang tidak sungguhsungguh untuk menggambar perangkat percobaan secara detail dan komunikatif, mengerjakan laporan tertulis, kesiapan presentasi, keterlibatan dalam tanya jawab, dan kemampuan menjelaskan keterkaitan antara masing-masing komponen kartu. Peningkatan kemampuan komunikasi maupun hasil belajar yang terjadi pada siklus II tampak lebih baik dibandingkan pada siklus I. Hal ini disebabkan siswa sudah dapat beradaptasi dan belajar dari lebih baik dari kegiatan belajar sebelumnya. Kegiatan belajar yang berkesinambungan merupakan proses yang secara tidak langsung akan membawa hasil yang lebih baik pada diri siswa. Grafik peningkatan kemampuan komunikasi siswa ditunjukkan oleh Gambar 6.

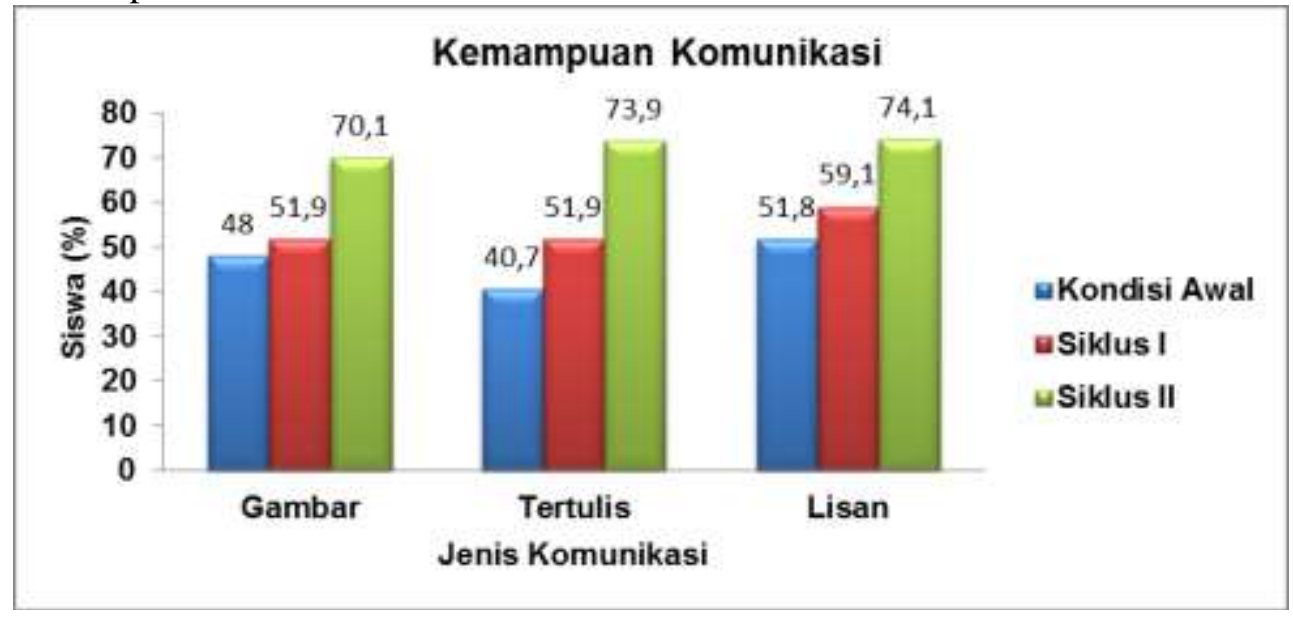

Gambar 6. Grafik Peningkatan Kemampuan Komunikasi Siswa SMP

Penelitian [13] yang dilakukan dalam dua siklus memberikan informasi bahwa penerapan siklus belajar 5-E yang dilengkapi LKS dapat meningkatkan kualitas proses dan hasil belajar siswa SMA. Dalam penerapan model ini, siswa dapat mempelajari materi secara bermakna dengan bekerja dan berfikir, pengetahuan dikonstruksi dari pengalaman siswa melalui penyelidikan dan penemuan untuk memecahkan masalah, kemudian siswa dapat mengungkapkan konsep yang sesuai dengan pengalamannya dan menggunakan pemahaman yang telah diperoleh untuk memecahkan permasalahan lain yang berhubungan dengan kehidupan sehari-hari. Dalam pembelajaran dengan siklus belajar 5-E siswa aktif bertanya, menjawab, mengerjakan soal ke depan, dan berdiskusi kelompok untuk memecahkan permasalahan dan menemukan konsep sendiri bersama kelompoknya sehingga akan memicu peningkatan rasa ingin tahu siswa dan minat siswa untuk belajar. Ketuntasan belajar siswa secara klasikal tampak pada Tabel 7 sebagai berikut.

Tabel 7. Ketuntasan Belajar Siswa SMA secara Klasikal

\begin{tabular}{|l|l|l|}
\hline \multirow{2}{*}{ Kategori } & \multicolumn{2}{|l|}{ Persentase (\%) } \\
\cline { 2 - 3 } & Siklus I & Siklus II \\
\hline Tuntas & 64,29 & 83,33 \\
\hline Tidak Tuntas & 35,71 & 16,67 \\
\hline
\end{tabular}

Penelitian [14] menyimpulkan bahwa implementasi model pembelajaran siklus belajar 5-E mampu menurunkan proporsi mahasiswa yang mengalami miskonsepsi pada konsep gaya, yakni dari $46 \%$ menjadi $2,8 \%$. Dengan demikian terdapat peningkatan proporsi penurunan jumlah mahasiswa yang mengalami miskonsepsi sebanyak 43,2\%. Diagram tingkat miskonsepsi mahasiswa tiap pertanyaan pada konsep gaya dapat dilihat pada Gambar 7. 


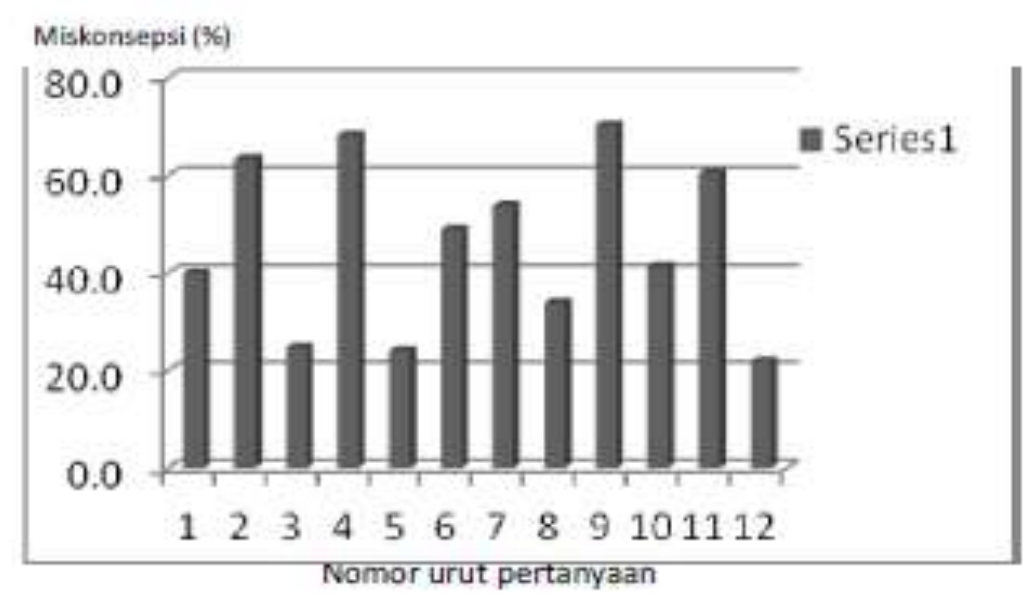

Gambar 7. Diagram tingkat miskonsepsi mahasiswa tiap pertanyaan konsep gaya

Dalam [14] dijelaskan bahwa sebelum mempelajari materi gaya, mahasiswa telah memiliki gagasan atau ide-ide tentang konsep yang dipelajari. Hal ini dapat dilihat dari profil konsepsi siswa yang cukup beragam pada pre-test menggunakan model CRI (Certainty of Response Index) dan juga ketika pembelajaran dengan model siklus belajar 5-E pada fase engage (menarik perhatian) yang merupakan fase awal dalam pembelajaran yang dilakukan dosen.

Pada fase engage ini dosen menciptakan situasi teka-teki yang sesuai dengan konsep gaya. Dosen mengajukan pertanyaan dalam rangka menggali prekonsepsi mahasiswa berkaitan dengan pemahamannya terhadap materi gaya, dan jawaban mahasiswa digunakan untuk mengetahui hal-hal apa saja yang telah diketahui oleh mereka. Pada fase inilah dosen mengidentifikasi miskonsepsi mahasiswa dengan memberikan pertanyaan dan paparan konsep yang membangkitkan konflik kognitif. Hasil yang dapat disampaikan peneliti ternyata konsepsi awal mahasiswa pada umumnya cukup bervariasi dan masih bersifat miskonsepsi.

Pada fase explore (eksplorasi), mahasiswa harus diberi kesempatan untuk bekerja sama dengan temantemannya tanpa arahan langsung dari dosen. Fase ini merupakan fase "ketidakseimbangan" dimana mahasiswa harus dibuat bingung. Fase ini merupakan kesempatan bagi mahasiswa untuk menguji hipotesis atau prediksi mereka, mendiskusikan dengan teman sekelompoknya dan menetapkan keputusan.

Pada fase explain (menjelaskan), dosen mendorong mahasiswa untuk menjelaskan konsep dengan kalimat mereka sendiri. Dosen memberikan kesempatan kepada mahasiswa secara individu maupun kelompok untuk mengungkapkan penjelasan terhadap suatu fenomena atau konsep tentang gaya.

Selanjutnya pada fase extend (perluasan), mahasiswa mengaplikasikan konsep dan kecakapan yang telah mereka miliki terhadap situasi lain tentang aplikasi konsep gaya. Dosen mendesain kegiatan yang serupa tetapi tidak sama dengan apa yang telah dilakukan sebelumnya, dan sifatnya merupakan pengembangan atau aplikasi dari konsep yang dipelajari. Sehingga pada fase inilah perubahan konsepsi mahasiswa dimantapkan, dari miskonsepsi ke konsepsi yang sesuai dengan konsepsi para ilmuan.

Pada fase evaluate (evaluasi) dilaksanakan oleh dosen selama pembelajaran dilangsungkan atau pada tiap siklus belajar yang sebelumnya telah disebutkan. Dosen mengobservasi pengetahuan dan kecakapan mahasiswa dalam mengaplikasikan konsep gaya dan perubahan berfikir mahasiswa.

\section{Penutup}

Penerapan model siklus belajar 5-E (Engage, Explore, Explain, Elaborate, Evaluate) dalam pembelajaran fisika merupakan salah satu upaya yang dapat digunakan guru untuk mencapai tujuan yang diharapkan. Berdasarkan hasil penelitian dari para pakar dan pemerhati pendidikan, model pembelajaran ini dapat mengembangkan kecakapan hidup siswa, disamping itu, model siklus belajar juga dapat diterapkan pada setiap jenjang pendidikan mulai dari jenjang sekolah dasar, menengah, hingga perguruan tinggi.

\section{REFERENSI}

[1] Jufri, A.W. Penerapan Pembelajaran Berbasis Inkuiri Secara Terpadu dengan Strategi Kooperatif dalam Mengembangkan Keterampilan Berpikir Kritis Siswa SMA di kota Mataram. Makalah dalam Seminar Nasional Pendidikan Sains, FKIP Unram, November 2007.

[2] Jufri, A.W. dan Hikmawati. Upaya Meningkatkan Kecakapan Hidup Siswa Melalui Pengembangan Model Pemberdayaan Kompetensi Profesional Guru Dalam Merancang Media Instruksional Sains Inovatif Berbasis Inkuiri. Laporan 
Penelitian Strategis Nasional. Mataram: Universitas Mataram, 2012.

[3] Kemendikbud. Materi Pelatihan Guru: Implementasi Kurikulum 2013. Jakarta: Badan Pengembangan Sumber Daya Manusia Pendidikan dan Kebudayaan dan Penjaminan Mutu Pendidikan, Kementerian Pendidikan dan Kebudayaan, 2013.

[4] Prince, M. Does Active Learning Work? A Review of the Research. Journal of Engineering Education, 93 (3), 223-231, July 2004.

[5] Anwar. Pendidikan Kecakapan Hidup (Life Skills Education). Bandung: Alfabeta, 2006.

[6] Khera, S. \& Khosla, S. A Study Of Core Life Skills Of Adolescents In Relation To Their Self Concept Developed Through YUVA School Life Skill Programme. IRJC, International Journal of Social Science \& Interdisciplinary Research, Vol.1 Issue 11, November 2012.

[7] Mugambi, M. M. \& Muthui, R. K. Influence Of Structural Context On Implementation Of Secondary School Life Skills Curriculum In Kajiado County, Kenya. International Journal of Education and Research, Vol. 1 No. 3 March 2013.

[8] Agustina, P. dan Saputra, A. Problematika Pelaksanaan Pembelajaran Biologi Berbasis Kecakapan Hidup (Life Skill) di Indonesia. Seminar Nasional IX Pendidikan Biologi FKIP UNS, 2012.

[9] Bass, J.E., et.al. Teaching Science as Inquiry (Eleventh Edition). USA: Pearson/Allyn \& Bacon, 2009.

[10] Bybee, R. W., et.al. The BSCS 5E Instructional Model: Origins and Effectiveness. A Report Prepared for the Office of Science Education, National Institutes of Health, Colorado, 2006.

[11] Astutik, S. Meningkatkan Hasil Belajar Siswa Dengan Model Siklus Belajar (Learning Cycle 5e) Berbasis Eksperimen Pada Pembelajaran Sains Di SDN Patrang I Jember. Jurnal Ilmu Pendidikan Sekolah Dasar, Vol 1 No 2 hal 143153, September 2012.

[12] Budiati, Herni. Implementasi Model Pembelajaran Learning Cycle 5e Secara Terpadu Dengan Permainan Kartu Link And Match Untuk Meningkatkan Kemampuan Komunikasi Pada Pembelajaran Biologi Siswa Kelas VIII F SMPN 22 Surakarta Tahun Pelajaran 2012/2013. Seminar Nasional X Pendidikan Biologi FKIP UNS, 2013.

[13] Utami, B., dkk. Penerapan Siklus Belajar 5E Disertai LKS Untuk Peningkatan Kualitas Proses
Dan Hasil Belajar Kimia. Cakrawala Pendidikan, Juni 2013, Th. XXXII, No. 2.

[14] Taufiq, M. Remediasi Miskonsepsi Mahasiswa Calon Guru Fisika Pada Konsep Gaya Melalui Penerapan Model Siklus Belajar (Learning Cycle) 5E. Jurnal Pendidikan IPA Indonesia, JPII 1 (2) (2012) 198-203.

[15] Prasetyo, Z. K., dkk. Kapita Selekta Pembelajaran Fisika. Jakarta: Universitas Terbuka, 2004.

[16] Akinbobola, A. O. \& Afolabi, F. Constructivist practices through guided discovery approach: The effect on students' cognitive achievement in Nigerian senior secondary school physics. Eurasian Journal of Physics and Chemistry Education. 2(1):16-25, 2010.

[17] Oladejo, M. A., et.al. Instructional Materials and Students' Academic Achievement in Physics: Some Policy Implications. European Journal of Humanities and Social Sciences, Vol. 2, No.1 (2011).

[18] Nur, M. Pengajaran Berpusat kepada Siswa dan Pendekatan Konstruktivis dalam Pengajaran. Surabaya: Unesa, 2004.

[19] Jufri, A. W. Belajar dan Pembelajaran Sains. Lombok Barat: Arga Puji Press, 2010.

[20] Jones, M. G. \& Araje, L. B. The Impact of Constructivism on Education: Language, Discourse, and Meaning. American Communication Journal, Volume 5, Issue 3, Spring 2002.

[21] Yuliati, Lia. Pengembangan Pembelajaran IPA SD. http://pjjpgsd.unesa.ac.id/dok/4.Modul-4Perencanaan\%20Pembelajaran\%20IPA.pdf akses tanggal 26 Desember 2014.

[22] Lawson, A. E. Using the learning cycle to teach biology concepts and reasoning patterns. Journal of Biological Education, (2001), (35), (4).

[23] Usmiatiningsih, E. 2013. Pengembangan Multimedia Interaktif Berbasis Flash dan Implementasinya melalui Model 5E untuk Meningkatkan Keterampilan Berpikir Kritis dan Sikap terhadap Sains. Tesis. Tidak diterbitkan. Mataram: Prodi Magister Pendidikan IPA PPs Universitas Mataram.

[24] Susiwi. Kecakapan Hidup (Life Skills). Bandung: UPI, 2007.

[25] Tim BBE Depdiknas. 2012. Pola Pelaksanaan Pendidikan Kecakapan Hidup. Surabaya: SIC.

[26] Suprihatiningrum, J. Strategi Pembelajaran. Jogjakarta: Ar-Ruzz Media. 
[27] Trianto. Mendesain Pembelajaran Kontekstual (Contextual Teaching and Learning) di Kelas. Jakarta: Cerdas Pustaka, 2008.

[28] Wilson, C. D., Taylor, J. A., Kowalski, S. M., \& Carlson, J. The relative effects and equity of inquiry-based and commonplace science teaching on students' knowledge, reasoning, and argumentation. Journal of Research in Science Teaching, (2010), 47(3), 276-301.

\section{Biografi Penulis}

Hikmawati, lahir di Montong Bulok, Lombok Tengah, 31 Desember 1981, menyelesaikan studi S1
Pendidikan Fisika di FKIP Universitas Mataram tahun 2003, sedangkan S2 Pendidikan Sains di Universitas Negeri Surabaya tahun 2009. Sejak tahun 2005 menjadi dosen tetap di Program Studi almamaternya dengan fokus kajian riset pada bidang pengembangan perangkat pembelajaran fisika. Bahan ajar yang telah diterbitkan adalah: (1) Kajian Fisika SMA; (2) Strategi Pembelajaran Fisika; (3) Perangkat Pembelajaran Fisika Berbasis Keunggulan Lokal. 